\title{
Pressure Signal Device
}

National Cancer Institute

\section{Source}

National Cancer Institute. Pressure Signal Device. NCI Thesaurus. Code C50119.

A device designed to monitor or display a pressure reading. 